\title{
Променада 2030
}

\author{
Весна Вуксан \\ Универзитет у Београду \\ Универзитетска библиотека „Светозар Марковић“, Београд \\ vesnavuksan@gmail.com
}

\begin{abstract}
Сажетак
С почетка 2016. године свет је почео да бруји о Агенди 2030, скованој у Уједињеним нацијама (УН) неколико месеци раније, коју су потписале 193 земље чланице. У Србију ова прича доспева пред очи јавности тек у току 2018. године, када медији објављују кратке прилоге са састанака високих државних функционера и невладиних организација, започиње се са кампањама, а портали и друштвени медији врве од фотографија, снимака и извештаја означених са \#GlobalGoals \#Serbia2030 \#UN2030.

Пре доношења Агенде 2030, представници Међународне федерације библиотечких удружења и институција (IFLA) активно и предано су заговарали за библиотеке у Уједињеним нацијама. Након три године преговора, IFLA је успела: библиотеке су постале део Агенде 2030. Сама реч „библиотека“ се не налази у овом документу, али приступ информацијама, културно наслеђе и универзална писменост чине његов саставни део.

Овај рад представиће улогу библиотека у остваривању циљева одрживог развоја, са посебним освртом на активности које су до сада организоване у Србији и могућности за будуће укључивање библиотека у националну агенду развоја.
\end{abstract}

Кључне речи: циљеви одрживог развоја, Агенда 2030, Уједињене нације, приступ информацијама, заговарање, IFLA, Библиотекарско друштво Србије, библиотеке

„Променада није шеталиште, променада је кад се надаш промени.“

Стефан Тићми ${ }^{1}$

\section{Улога библиотека у глобалним циљевима}

Библиотекама није тешко. Није им тешко да учествују у остваривању глобалних циљева зацртаних у Агенди УН 2030, ${ }^{2}$ није им тешко ни да доприносе националним циљевима који су усредсређени на побољшање људских живота и заједница у Србији. Зашто?

Сваки дан, библиотекари одлазе на посао и практично све што раде, осмишљавају и реализују утиче на људске животе. Услуге, програми и пројекти попут раног описмењавања, часова креативног писања, еколошке радионице за најмлађе, помоћ при тражењу посла или изради семинарских радова, подстицај иновацијама, приступ информацијама, дигитализација и очување културне баштине, безбедни и инклузивни простори за сусрете и учење, представљају само део понуде која утиче на квалитет живота појединаца и заједнице коју библиотека опслужује.

Међутим, уместо да библиотеке увелико учествују у планирању и активностима везаним за циљеве одрживог развоја на националном нивоу, данас владин сектор, канцеларија Уједињених нација у Србији и организације цивилног друштва стварају документе и развијају

\footnotetext{
${ }^{1}$ Стефан Тићми, Ја сам Акико (Београд: Лагуна, 2018), 23.

2 Ujedinjene Nacije (UN), "Historic New Sustainable Development Agenda Unanimously Adopted by 193 UN Members", preuzeto 1. 8. 2018, https://www.un.org/sustainabledevelopment/blog/2015/09/historic-new-sustainable-development-agenda-unanimouslyadopted-by-193-un-members/.
} 
стратегије које ће одредити и судбину библиотека - а то раде без библиотека. На важним састанцима попут Регионалног форума о одрживом развоју у Женеви ${ }^{3}$ или Политичког форума на високом нивоу у Њујорку, ${ }^{4}$ често се чују изјаве светских лидера како су партнерства између јавног, приватног и цивилног сектора изузетно значајна те да владе не могу саме да постигну циљеве: потребни су им појединци, заједнице, представници друштва.

„IFLA заступа став да је приступ информацијама кључан у остваривању циљева одрживог развоја. Библиотеке нису само важни партнери владама у наредним годинама, већ оне увелико доприносе остварењу свих 17 циљева кроз услуге, програме и пројекте које спроводе у својим заједницама. ${ }^{\prime 5}$

Премијерка Србије, Ана Брнабић, изјавила је недавно да су „циљеви глобални, али су путеви ка њиховом остварењу другачији у свакој земљи, а спровођење заједнички посао владе, цивилног друштва, академске заједнице, локалних заједница и међународних институција. “6

Зашто се онда доносиоци одлука нису сетили да позову библиотеке у помоћ? Да ли су библиотеке довољно јасне, гласне и упорне; умеју ли да испричају своју причу речником слушалаца, тако да их они разумеју, или чешће говоре о себи?

\section{Стратешки циљеви Србије}

Уколико истраживач пожели да се бави темом циљева одрживог развоја и стратешких планова Србије, наићи ће на бројне изазове. Постоје веб-странице које би морале понудити актуелне информације о стању у Србији: Ко се бави овом темом на највишем нивоу? Ко су чланови групе која је задужена за креирање стратегије? Где смо у овом тренутку? Шта је било на последњем састанку поменуте групе? Да ли је Влада Републике Србије утврдила приоритетне циљеве које планира по први пут да представи у јулу 2019. године на најважнијем састанку о одрживом развоју у Уједињеним нацијама? ${ }^{7}$

Већ почетком 2016. године креиран је веб-сајт „Циљеви одрживог развоја“" који ће представљати меродаван извор информација у вези са глобалним циљевима у Србији. Међутим, поред тога што је нејасно ко тачно стоји иза ове веб-странице, ${ }^{9}$ последња вест на почетној страни објављена је пре више од годину дана, тачније 29. септембра 2017. године. С друге стране, веб-странице Уједињених нација у Србији нуде најсвежије информације у вези са дешавањима, одржаним састанцима и покренутим кампањама; но, ове странице садрже интересантну комбинацију српско-енглеских описа и графичких решењ ${ }_{1}^{10}$ па свако ко је заинтересован за верзију на српском језику мора да се потруди да преведе сегменте ових текстова. За све што недостаје на главном УН веб-сајту, допунске информације могу се пронаћи на другим страницама, као што су, на пример, вести UNICEF-а, које међу реткима данас дају одговор на важно питање: шта је Србија дефинисала као стратешке циљеве развоја?

\footnotetext{
${ }^{3}$ Regional Forum for Sustainable Development (RFSD), Ženeva 1. i 2. 3. 2018, preuzeto 1. 8. 2018, https://www.unece.org/rfsd2018.html. ${ }^{4}$ High Level Political Forum (HLPF), održava se u Njujorku svake godine u julu, preuzeto 1. 8. 2018, https://sustainabledevelopment. un.org/hlpf/2018.

${ }^{5}$ IFLA, "Libraries, Development and the United Nations 2030 Agenda", preuzeto 2. 9. 2018, https://www.ifla.org/libraries-development. ${ }^{6}$ PTC, „Брнабић: Циљ Агенде 2030 да нико не остане на крају колоне“, објављено 13. 9. 2018, преузето 14. 9. 2018, http://www.rts. rs/page/stories/sr/story/9/politika/3256747/brnabic-cilj-agende-2030-da-niko-ne-ostane-na-kraju-kolone.html.

${ }^{7}$ United Nations Sustainable Development Knowledge Platform, Serbia, preuzeto 20. 9. 2018, https://sustainabledevelopment.un.org/ index. php? page $=$ view\&type $=30022 \& n r=1130 \&$ menu $=3170$.

${ }^{8}$ SeConS, Циљеви одрживог развоја, preuzeto 25. 9. 2018, http://www.ciljeviodrzivograzvoja.net/.

9 Група за развојну иницијативу "SeConS“ наведена је као контакт. У циљу провере кредибилитета, увек мора постојати узајамни линк између две странице. На веб-сајту групе secons.net не налази се директан линк ка сајту ciljeviodrzivograzvoja.net; међутим, однедавно је у оквиру SeConS сајта уведен поддомен „Развојна опсерваторија“, који указује на везу ове групе са радом на циљевима secons.net/do.

10 УНдП у Србији, „Циљеви одрживог развоја“, преузето 1. 9. 2018, http://www.rs.undp.org/content/serbia/sr/home/sustainable-development-goals.html.
} 
„Пет стратешких циљева дефинисани су у складу са националним развојним приоритетима Владе Р. Србије и потпуно су усклађени са процесом ЕУ интеграција и Агендом 2030. Оквир развојног партнерства (ОРП), потписан недавно, између Владе Р. Србије и УН тима за период 2016-2020 представља путоказ за стратешку сарадњу на даљем унапређивању добре управе и владавине права, развоја социјалних и људских ресурса, привредном развоју, расту и запошљавању, заштити животне средине, борби против климатских промена и изградњи отпорних заједница, као и интегрисању културе у целокупни процес одрживог развоја." 11

Из овог текста, а у односу на 17 циљева одрживог развоја, може се закључити да Србија приоритете види у следећим циљевима: 1 = Без сиромаштва, $4=$ Квалитетно образовање, $8=$ Достојанствен рад и економски раст, 11 = Одрживи градови и заједнице, 13 = Климатске промене, 15 = Живот на земљи и 16 = Мир, правда и снажне институције. Култура коју Влада Републике Србије жели да интегрише у целокупни процес одрживог развоја налази се у званичној Агенди 2030 као потциљ 11.4 „Оснажити заштиту и очување светске културне и природне баштине“, ${ }^{12}$ а потциљ 16.10 гласи „Осигурати јавни приступ информацијама и заштитити основне слободе у складу са националним законима и међународним договорима“.

Библиотекари, препознајете ли свој рад?

\section{IFLA зове Србију}

У току претходне две године, библиотекари Србије вредно су се спремали за циљеве одрживог развоја кроз учешће у истраживањима, радионицама и конференцијама. Све је почело у децембру 2016. године, када је стигао позив из седишта IFLA-е ауторки овог текста да узме учешће у радионици „Улога библиотека у Агенди УН 2030“13 која се одржавала у Хагу у Холандији. Радионица је настала у оквиру IFLA Међународног програма за заговарање, ${ }^{14}$ осмишљеног са циљем пружања подршке библиотекама у процесу планирања и примене Агенде 2030 и циљева одрживог развоја. Концепт радионице заснован је на идеји да се библиотекарима приближи веза између онога што раде на својим пословима са циљевима одрживог развоја; да науче како да заступају интересе библиотека у овом домену и да ефектно објасне доносиоцима одлука колико су им библиотеке важне у процесу постизања глобалних циљева на националном нивоу.

Суштинска последица тродневне радионице замишљена је као низ каскадних ${ }^{15}$ радионица широм Европе. Сваки полазник потписао је уговор у ком се обавезао да ће даље радити на подизању свести библиотекара о важној улози библиотека у остваривању УН агенде те да ће учествовати у састанцима са доносиоцима одлука и интересним групама. Активности свих учесника су праћене путем извештаја које је IFLA објављивала у периоду од јануара до октобра 2017. године. ${ }^{16}$

У оквиру пројеката јачања капацитета, IFLA има тенденцију да сарађује са националним библиотекарским удружењима (уместо са одређеним библиотекама), јер приоритетно представља федерацију библиотекарских удружења, а с друге стране, удружење види као платформу која може остварити највећи утицај у једној земљи. Тако је Библиотекарско друштво Србије (БДС), као најшири полигон за размену знања у струци, у току 2017. и до октобра 2018.

\footnotetext{
11 UNICEF Србија, „Оснаживање Србије кроз циљеве одрживог развоја“, преузето 1. 9. 2018, https://www.unicef.org/serbia/ press-releases/osna\%C5\%BEivanje-srbije-kroz-ciljeve-odr\%C5\%BEivog-razvoja.

12 SDSN, "Indicators and a Monitoring Framework", preuzeto 1. 9. 2018, http://indicators.report/targets/11-4/.

13 IFLA, "European Regional Workshop of the International Advocacy Programme", preuzeto 10. 9. 2018, https://www.ifla.org/ node/11047.

${ }^{14}$ IFLA, "The International Advocacy Programme", preuzeto 10. 9. 2018, https://www.ifla.org/ldp/iap.

15 Каскадне радионице подразумевају преношење знања на одређени број учесника који у наредном кораку постају предавачи и делају као преносиоци знања следећој групи учесника итд.

${ }^{16}$ IFLA, “International Advocacy Programme (IAP) Update - October 2017“, preuzeto 11. 9. 2018, https://www.ifla.org/node/16732.
} 
године организовало, у девет наврата, радионицу „Ко то тамо прича?“. ${ }^{17}$ Акредитовани семинар $^{18}$ „Ко то тамо прича?" ауторки Весне Вуксан и Милене Костић из Универзитетске библиотеке „Светозар Марковић“ заснован је на концепту IFLA радионица Међународног програма за заговарање и бави се заговарањем, библиотекама и Агендом 2030. Поред увода у Агенду 2030, током радионице стварају се везе између свакодневних активности, програма и услуга библиотеке са глобалним циљевима којима се тежи; затим, полазници имају прилику да покажу своје вештине заговарања и преговарања; у циљу постизања договора користе се аргументи који нису само статистички, већ подразумевају и причу о утицају библиотеке на нечији живот, дакле, личне приче које изазивају емотивне реакције код слушалаца. У току процеса заговарања на радионицама, фокус је стално на слушаоцу, а не на ономе који говори; тако библиотеке, када желе да добију подршку, не би требало да говоре о себи, већ о заједници, односно о томе какав интерес од тога има доносилац одлуке. Оно што чини ове радионице најатрактивнијим јесте управо стављање полазника у улогу креатора нових знања; након шест сати обуке, сваки учесник је спреман не само да пренесе знање на друге колеге и да будуће кампање и активности брендира циљевима одрживог развоја, већ и да својим идејама допринесе подизању свести заједнице о Агенди 2030 и да подстакне појединце да и сами нешто ураде.

Радионице су до сада одржане у Горњем Милановцу, Осечини, Пожеги, Зрењанину, Новом Саду, Обреновцу и неколико пута у Београду. Преко две стотине полазника из свих типова библиотека, током овог периода, имало је прилику да се упозна са циљевима одрживог развоја те да препозна свој свакодневни посао и улогу у реализацији циљева. Интересовање је и даље велико, утолико што су у току преговори да се до краја 2018. године семинар одржи у Пироту, Прокупљу, Јагодини и Новом Саду.

У низу активности везаних за тему УН Агенде, природно је дошла и тема годишње конференције БДС одржане у децембру 2017. године „О чему говорим када говорим о библиотекама: заговарање, промовисање, лобирање.${ }^{19}$ Подизање свести је успело!

\section{БДС координатор IFLA пројеката}

Након иницијалног успеха радионица о јавном заговарању и циљевима одрживог развоја, било је потребно направити корак даље. У току 2017. године, IFLA Међународни програм за заговарање два пута је расписао конкурсе и оба пута су пројекти које предводи БДС одобрени.

У првој рунди, пројекат Stories That Matter \#MadeInTheLibrary ${ }^{20}$ освојио је високе оцене због концепта у садржинском и географском смислу. Поред основне замисли да се кроз пројекат прикупљају успешне приче из библиотека целог света као снажни аргументи у заговарању, IFLA је подигла идеју на још импозантнији ниво: Stories су укључене у Мапу света библиотека (Library Map of the World), ${ }^{21}$ као један од најважнијих стратешких пројеката које IFLA тренутно развија. Сарадници БДС-а на пројекту су библиотечка удружења из Летоније, САД-а, Мексика, Колумбије, Египта, Сенегала и Филипина. Један од конкретних резултата пројекта у овом тренутку, поред мапе са причама, јесте Приручник за ириче 22 који је објавила IFLA, а чији ће се превод на српски језик до краја 2018. године наћи на веб-страници Библиотекарског друштва

\footnotetext{
${ }_{17}$ Библиотекарско друштво Србије, „Едукација: Ко то тамо прича?“, преузето 12. 9. 2018, http://bds.rs/wordpress/?page_id=20.

18 Народна библиотека Србије, „Одлука о акредитацији програма сталног стручног усавршавања у библиотечко-информационој делатности за 2018. годину“, преузето 12. 9. 2018, https://www.nb.rs/view_file.php?file_id=5569.

${ }^{19}$ Библиотекарско друштво Србије, „О чему говорим када говорим о библиотекама: заговарање, промовисање, лобирање“, преузето 12. 9. 2018, https://bdskonferencija2017.wordpress.com/

${ }^{20}$ Библиотекарско друштво Србије, "Stories that Matter", преузето 13. 9. 2018, https://biblioteke2030.wordpress.com/ stories-that-matter/.

${ }^{21}$ IFLA, Library Map of the World, SDG Stories, preuzeto 13. 9. 2018, https://librarymap.ifla.org/stories.

22 IFLA, Libraries and the Sustainable Development Goals: a storytelling manual, preuzeto 15. 9. 2018, https://www.ifla.org/files/assets/hq/ topics/libraries-development/documents/sdg-storytelling-manual.pdf.
} 
Србије. ${ }^{23}$ Аутори овог приручника су представници партнерских удружења, а уједно и полазници IFLA програма за лидере. ${ }^{24}$ Оно што следи до краја текуће године су и видео-туторијали који прате приручник и служе као водич за ефектно причање о успешним програмима, пројектима и услугама у контексту глобалних циљева. Видео-туторијали ће се наћи на друштвеним мрежама IFLA-е, а биће отворени за превод на све језике света. Уколико се међу библиотекарима из Србије нађу волонтери вољни да учествују у превођењу, ови водичи за успешније причање прича биће доступни и на српском језику.

У другој рунди позива за достављање пројеката, IFLA указује поверење регионалном пројекту који координира БДС, а као партнери учествују Хрватско књижничарско друштво (ХКД), Асоцијација информацијских стручњака - библиотекара, архивиста и музеолога (БАМ) и Друштво библиотекара правних и сродних библиотека Југоисточне Европе. У оквиру овог пројекта, од јануара до јуна 2018. године, одржане су радионице у Загребу, Београду и Мостару. Иако различите у појединим сегментима, суштински су пратиле концепт IFLA Међународног програма за заговарање - уз извесна побољшања. Поред предавача из Србије, Хрватске и Босне и Херцеговине који су говорили о искуствима и идејама из струке, на радионици одржаној у мају 2018. године у Београду ${ }^{25}$ учествовали су и Карла Робин Херши, стална координаторка УН-а у Србији, Александра Владисављевић, предузетница која се бави друштвеним иновацијама, Младен Ђукић, редитељ који је говорио о ефектном кратком филму, а све је било зачињено интерактивношћу, несвакидашњим идејама и креативним решењима полазника. Иако одржана у Београду, циљ радионице није био да окупи београдске библиотекаре, већ је фокус био на окупљању библиотекара из што већег броја подружница БДС-а из целе Србије. Радионици је присуствовало тридесет полазника, а међу њима се нашло и пет студената Катедре за библиотекарство и информатику Филолошког факултета Универзитета у Београду. БДС на тај начин подстиче и будуће колеге да се укључе у активности, али и да их саме организују и подстакну и друге да се придруже. Овакав приступ је и део Глобалне визије IFLA-е која, међу десет најважнијих фокуса струке за будућност, наводи да „младим стручњацима морамо пружити могућност да уче, развијају идеје и постану лидери“. ${ }^{26}$

Карла Робин Херши је на радионици у Београду потврдила још једном став Уједињених нација по питању улоге библиотека: „Тим Уједињених нација у Србији посвећен је подршци Влади, народу Србије и свим партнерима који поспешују имплементацију Агенде 2030. У нашем петогодишњем развојном плану за Републику Србију определили смо простор за рад на образовању, промоцији културе, промоцији једнакости полова и многих других циљева који су релевантни за наше данашње окупљање. Радујемо се и желимо добродошлицу библиотекама Србије као нашим партнерима. ${ }^{27}$

\section{Приче као аргументи}

У заговарању и лобирању од суштинског значаја је умети сажето и ефектно испричати своју причу. Све популарнији сегмент радионица из ове области представља тзв. "elevator pitch", тj. „продаја“ приче у лифту; дужина вожње у лифту сразмерна је времену које је потребно да освојите нечију пажњу.

\footnotetext{
${ }_{23}^{23}$ Библиотекарско друштво Србије, „Библиотеке 2030“, преузето 13. 9. 2018, https://2030.bds.rs.

${ }^{24}$ IFLA, "A Leaders Journey Begins", preuzeto 14. 9. 2018, https://www.ifla.org/node/10801.

${ }^{25}$ Библиотекарско друштво Србије, „Одржана ИФЛА-БДС радионица о библиотекама и УН 2030“, преузето 23. 6. 2018, http://bds rs/wordpress/?p=2550.

${ }^{26}$ IFLA, "Global Vision Report Summary", preuzeto 11. 9. 2018, https://www.ifla.org/files/assets/GVMultimedia/publications/gv-report-summary.pdf.

27 Карла Робин Херши, “Libraries and UN 2030“ (уводни говор на отварању радионице Улога библиотека у остваривању циљева одрживог развоја одржаној у Универзитетској библиотеци „Светозар Марковић“, Београд, Србија, 28-29. 5. 2018).
} 
Током реализације регионалног IFLA-БДС пројекта, сакупљане су и приче из библиотека. Циљ је био стварање везе између услуга и програма који се одвијају у библиотекама, са циљевима одрживог развоја. Након тога, приче се шаљу на адресу IFLA Светске мапе библиотека, ${ }^{28}$ како би све биле доступне на једном месту и на тај начин послужиле као аргументи у заговарању не само у Србији, већ и шире. Иако је анкета спроведена на самом почетку пројекта, када се још недовољно знало о овој теми, сакупљени су вредни одговори из целе земље. На питање како одређене библиотеке утичу на смањење сиромаштва (Циљ 1), неки од одговора су били „Социјално угрожене особе не плаћају чланарину“, „Спроводимо хуманитарне акције прикупљања помоћи“, „Организујемо курсеве за писање радне биографије и пријављивање за посао“. На питање о смањењу глади (Циљ 2), библиотеке „обављају консултантске услуге са пољопривредним газдинствима у писању пројеката“, „организују едукативна предавања из области пољопривреде“. Када је реч о добром здрављу (Циљ 3), библиотеке организују "трибине о болестима зависности“, "посећују болнице и дарују играчке“, организују пројекат „Жива библиотека“. Библиотекари су били најактивнији у одговору на питање о квалитетном образовању (Циљ 4) и навели „едукативне радионице за све, посебно маргинализоване групе у домовима и сиротиштима“, "помоћ при домаћим задацима и припреме за пријемни испит“, "алати у отвореном приступу", и сл. Уследили су одговори и на све остале циљеве, као што су: равноправност полова (Циљ 5) „повезивање са удружењима жена“, чиста вода (Циљ 6) „Захваљујућу нашој библиотекарки, село је добило нове пумпе за воду" и слично.

Овде, свакако, није крај: приче се прикупљају и даље, ${ }^{29}$ посебно с обзиром на чињеницу да су се у првом позиву прикупљале кратке изјаве о одржаним програмима, пројектима и услугама, а идеја је да се у другом позиву приче пишу према упутствима из IFLA Прируиника за ириче. ${ }^{30}$

\section{Поглед у блиску будућност: 2019}

Главни састанак о одрживом развоју, који се одржава у Њујорку од 2016. године сваког јула, има неколико изабраних циљева који представљају фокус за ту годину. Тако 2019. доноси следеће кључне области: Квалитетно образовање (циљ 4), Достојан рад и економски раст (циљ 8), Смањење неједнакости (циљ 10), Акција за климу (циљ 13), Мир, правда и снажне институције (циљ 16) и Партнерства за циљеве (циљ 17). ${ }^{31}$ Овакав избор идеалан је за библиотекаре, јер своју улогу лако препознају у образовању, приступу информацијама, доживотном учењу, стицању вештина за бољи посао; уједно, како Србија први пут подноси нацрт националног плана баш тада, биће интересантно анализирати приоритете на глобалном и локалном нивоу.

До овог тренутка, библиотекари Србије остварили су значајна партнерства у контексту циљева одрживог развоја, са Уједињеним нацијама, представницима министарстава и неким од водећих организација цивилног друштва. Србија је имала представнике-библиотекаре на најважнијим састанцима УН у Женеви ${ }^{32}$ и Њујорку. ${ }^{33}$ Захваљући радионицама и пројектима, велики број библиотекара у Србији данас има чврсто знање о УН Агенди и циљевима. Реализоване

28 IFLA, "Library Map of the World", preuzeto 12. 9. 2018, https://librarymap.ifla.org/stories.

${ }_{29}$ Библиотекарско друштво Србије, „Анкета: Библиотеке и глобални циљеви“, преузето 15. 9. 2018, https://docs.google.com/ forms/d/e/1FAIpQLSf-IUW5vFkk03jstx08DnJR6LV3v4xmhrgRZmWK5QWib5E_yw/viewform.

${ }^{30}$ Информација о наредном кораку прикупљања прича о успешним услугама, програмима и пројектима библиотека у Србији биће правовремено објављена на веб-сајту БДС.

31 IISD, "High-level Political Forum on Sustainable Development (HLPF) 2019", preuzeto 13. 9. 2018, http://sdg.iisd.org/events/ high-level-political-forum-on-sustainable-development-hlpf-2019/.

${ }^{32}$ Библиотекарско друштво Србије, „Регионални форум о одрживом развоју“, објављено 5. 3. 2018, преузето 13. 9. 2018, http://bds. $\mathrm{rs} /$ wordpress/?p=2435.

${ }^{33}$ Библиотекарско друштво Србије, „Данас у Њујорку: развој и приступ информацијама“, објављено 17. 7. 2017, преузето 12. 9. 2018, http://bds.rs/wordpress/?p=2038. 
су активности усмерене ка промоцији циљева, као што је недавно одржан фестивал Чиіра у Пожеги, ${ }^{34}$ где је цео сегмент био посвећен Агенди 2030 из дечјег угла; пројекат Кюиіе йовезуjу љуgе у сарадњи БДС и Амбасаде Сједињених Америчких Држава у Београду представио је Агенду 2030 најширој јавности; Београдска политехника је организовала акцију „Ми смо одлучили! Да очистимо Звездарску шуму!“, 35 Универзитетска библиотека у Београду покренула је кампању „2030“. ${ }^{36}$ Библиотекари из Србије помогли су IFLA-и у креирању докумената као

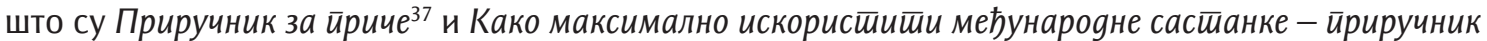
за йреgставнике IFLA-e. ${ }^{38}$ У извештајима ове глобалне организације, приче о успесима библиотекара из Србије заузимају и по неколико страница. ${ }^{39}$

Шта даље?

До 2030. године остало је још 11 година, тачније, око 4400 дана.

Мото Агенде УН 2030 гласи: „Нико неће остати иза / Noone will be left behind“. ${ }^{40}$

Библиотеке би требало да покажу доносиоцима одлука и владама својих земаља колико су важне за достизање циљева одрживог развоја, односно побољшање сваког људског живота. Зато, нека мото библиотекара Србије буде „Циљева је 17, библиотека пуно више!“. ${ }^{41}$ Јер, ако неко може да оствари ову ироменаgу, то ће бити довитљиви, креативнии знањем потковани библиотекари!

\section{Литература и извори:}

1. Beogradska politehnika. „Mi smo odlučili! Da očistimo Zvezdarsku šumu!“. Jutjub, 8. 6. 2018. https:// www.youtube.com/watch?v=aMTzpxrqBq8.

2. Bibliotekarsko društvo Srbije. "Anketa: Biblioteke i globalni ciljevi“. Preuzeto 15. 9. 2018. https://docs. google.com/forms/d/e/1FAIpQLSf-IUW5vFkk03jstx08DnJR6LV3v4xmhrgRZmWK5QWib5E_yw/viewform.

3. Bibliotekarsko društvo Srbije. „Biblioteke 2030“. Preuzeto 13. 9. 2018. https://2030.bds.rs.

4. Bibliotekarsko društvo Srbije. "Ciljeva je 17, biblioteka puno više!“. Preuzeto 1. 10. 2018. http://bds.rs/ wordpress/?p=2494.

5. Bibliotekarsko društvo Srbije. „Danas u Njujorku: razvoj i pristup informacijama“. Objavljeno 17. 7. 2017. Preuzeto 12. 9. 2018. http://bds.rs/wordpress/?p=2038.

6. Bibliotekarsko društvo Srbije. „Edukacija: Ko to tamo priča?“. Preuzeto 12. 9. 2018. http://bds.rs/ wordpress/?page_id=20.

7. Bibliotekarsko društvo Srbije. „O čemu govorim kada govorim o bibliotekama: zagovaranje, promovisanje, lobiranje“. Preuzeto 12. 9. 2018. https://bdskonferencija2017.wordpress.com/.

8. Bibliotekarsko društvo Srbije. „Održana IFLA-BDS radionica o bibliotekama i UN 2030“. Preuzeto 23. 6. 2018. http://bds.rs/wordpress/?p=2550.

\footnotetext{
34 „Фестивал Чигра у Пожеги“, Данас, преузето 2. 10. 2018, https://www.danas.rs/drustvo/festival-slikovnica-cigra-u-pozegi-od-3-do5-oktobra/.

${ }^{35}$ Београдска политехника, „Ми смо одлучили! Да очистимо Звездарску шуму!“, Јутјуб, 8. 6. 2018, https://www.youtube.com/ watch?v=aMTzpxrqBq8.

36 Универзитетска библиотека „Светозар Марковић“, Фејсбук, 4. 10. 2018, https://www.facebook.com/UNILIB/photos/a.7088211358 $80757 / 1896081010488091 /$ ?type=3\&theater.

${ }^{37}$ IFLA, Libraries and the Sustainable Development Goals: a storytelling manual.

${ }_{38}$ IFLA, Making the Most of International Meetings - A Playbook for IFLA representatives, preuzeto 15. 9. 2018, https://www.ifla.org/files/ assets/hq/topics/libraries-development/documents/international_meetings_playbook.pdf.

39 IFLA, "International Advocacy Programme (IAP) Update - October 2017", preuzeto 11. 9. 2018. https://www.ifla.org/node/16732.

${ }^{40}$ UNDP, "What Does It Mean to Leave Noone Behind", preuzeto 11. 9. 2018, http://www.undp.org/content/undp/en/home/librarypage/poverty-reduction/what-does-it-mean-to-leave-no-one-behind-.html.

${ }^{41}$ Библиотекарско друштво Србије, „Циљева је 17, библиотека пуно више!“, преузето 1. 10. 2018, http://bds.rs/wordpress/?p=2494
} 
9. Bibliotekarsko društvo Srbije. „Regionalni forum o održivom razvoju“. Objavljeno 5. 3. 2018. Preuzeto 13. 9. 2018. http://bds.rs/wordpress/?p=2435.

10. Bibliotekarsko društvo Srbije. Stories that Matter. Preuzeto 13. 9. 2018. https://biblioteke2030. wordpress.com/stories-that-matter/.

11. Herši, Karla Robin. "Libraries and UN 2030". Uvodni govor na otvaranju radionice Uloga biblioteka u ostvarivanju ciljeva održivog razvoja održanoj u Univerzitetskoj biblioteci "Svetozar Marković" Beograd, Srbija, 28-29. 5. 2018.

12. High Level Political Forum (HLPF). Preuzeto 1. 8. 2018. https://sustainabledevelopment.un.org/ hlpf/2018.

13. IFLA. "A Leaders Journey Begins". Preuzeto 14. 9. 2018. https://www.ifla.org/node/10801.

14. IFLA. "European Regional Workshop of the International Advocacy Programme". Preuzeto 10. 9. 2018. https://www.ifla.org/node/11047.

15. IFLA. "Global Vision Report Summary". Preuzeto 11. 9. 2018. https://www.ifla.org/files/assets/ GVMultimedia/publications/gv-report-summary.pdf.

16. IFLA. "International Advocacy Programme (IAP) Update - October 2017". Preuzeto 11. 9. 2018. https://www.ifla.org/node/16732.

17. IFLA. Libraries and the Sustainable Development Goals: a storytelling manual. Preuzeto 15. 9. 2018. https:// www.ifla.org/files/assets/hq/topics/libraries-development/documents/sdg-storytelling-manual.pdf.

18. IFLA. "Libraries, Development and the United Nations 2030 Agenda". Preuzeto 2. 9. 2018. https:// www.ifla.org/libraries-development.

19. IFLA. "Library Map of the World". Preuzeto 12. 9. 2018. https://librarymap.ifla.org/stories.

20. IFLA. Making the Most of International Meetings - A Playbook for IFLA representatives. Preuzeto 15. 9. 2018. https://www.ifla.org/files/assets/hq/topics/libraries-development/documents/international_ meetings_playbook.pdf.

21. IFLA. "The International Advocacy Programme". Preuzeto 10. 9. 2018. https://www.ifla.org/ldp/iap.

22. IISD. "High-level Political Forum on Sustainable Development (HLPF) 2019". Preuzeto 13. 9. 2018. http://sdg.iisd.org/events/high-level-political-forum-on-sustainable-development-hlpf-2019/.

23. Narodna biblioteka Srbije. „Odluka o akreditaciji programa stalnog stručnog usavršavanja u bibliotečko-informacionoj delatnosti za 2018. godinu“. Preuzeto 12. 9. 2018. https://www.nb.rs/view_ file.php?file_id=5569.

24. Regional Forum for Sustainable Development (RFSD). Ženeva 1. i 2. 3. 2018. Preuzeto 1. 8. 2018 https://www.unece.org/rfsd2018.html.

25. RTS. „Brnabić: Cilj Agende 2030 da niko ne ostane na kraju kolone“. Objavljeno 13. 9. 2018. Preuzeto 14. 9. 2018. http://www.rts.rs/page/stories/sr/story/9/politika/3256747/brnabic-cilj-agende-2030-daniko-ne-ostane-na-kraju-kolone.html.

26. SDSN. "Indicators and a Monitoring Framework". Preuzeto 1. 9. 2018. http://indicators.report/ targets/11-4/.

27. SeConS. Ciljevi održivog razvoja. Preuzeto 25. 9. 2018. http://www.ciljeviodrzivograzvoja.net/.

28. Tićmi, Stefan. Ja sam Akiko. Beograd: Laguna, 2018.

29. Ujedinjene nacije (UN). "Historic New Sustainable Development Agenda Unanimously Adopted by 193 UN Members". Preuzeto 1. 8. 2018. https://www.un.org/sustainabledevelopment/blog/2015/09/ historic-new-sustainable-development-agenda-unanimously-adopted-by-193-un-members/.

30. UNDP u Srbiji. „Ciljevi održivog razvoja“. Preuzeto 1. 9. 2018. http://www.rs.undp.org/content/serbia/ sr/home/sustainable-development-goals.html.

31. UNDP. "What Does it Mean to Leave Noone Behind". Preuzeto 11. 9. 2018. http://www.undp.org/content/ undp/en/home/librarypage/poverty-reduction/what-does-it-mean-to-leave-no-one-behind-.html.

32. UNICEF Srbija. „Osnaživanje Srbije kroz ciljeve održivog razvoja“. Preuzeto 1. 9. 2018. https://www. unicef.org/serbia/press-releases/osna\%C5\%BEivanje-srbije-kroz-ciljeve-odr\%C5\%BEivog-razvoja.

33. United Nations Sustainable Development Knowledge Platform. Serbia. Preuzeto 20. 9. 2018. https:// sustainabledevelopment.un.org/index.php?page=view\&type $=30022 \& n r=1130 \&$ menu $=3170$. 
34. Univerzitetska biblioteka „Svetozar Marković". Fejsbuk, 4. 10. 2018. https://www.facebook.com/ UNILIB/photos/a.708821135880757/1896081010488091/?type=3\&theater.

35. „Festival Čigra u Požegi“. Danas. Preuzeto 2. 10. 2018. https://www.danas.rs/drustvo/

festival-slikovnica-cigra-u-pozegi-od-3-do-5-oktobra/.

\section{Promenade 2030}

\section{Summary}

At the beginning of 2016, the whole world started talking about a new global agenda. Designed to end poverty by 2030 and pursue a sustainable future, it was unanimously adopted by the 193 Member States of the United Nations (UN). The citizens of Serbia started hearing more about the Sustainable Development Goals (SDGs) in 2018, as media began to report more intensively on meetings of government representatives, NGOs and other stakeholders, and a number of campaigns taking place while portals and social media started buzzing with images, recordings and reports tagged with \#GlobalGoals \#Serbia2030 \#UN2030.

Before the Agenda 2030 was made official, IFLA representatives actively advocated for libraries in the UN meetings. After three years of negotiations, in 2015, libraries became part of the UN 2030 Agenda. The word library is not mentioned in this document, however, access to information, cultural heritage and universal literacy are parts of it. This moment opened the doors for libraries worldwide to take their seats in the national development plans meetings. The road to reach such point is not easy and this is why IFLA decided to invest in capacity building in all regions of the world and train librarians how to be great advocates in the UN 2030 context and tell their stories better. As for Serbia, this opened numerous opportunities: from attending IFLA International Advocacy Programme training, getting recognized by the National Library of Serbia and supported by the University Library in Belgrade to organize similar trainings in Serbia throughout 2017 and 2018 for over 200 librarians as a part of education program of the Serbian Library Association; being part of IFLA delegation at the most significant SDGs meetings such as High Level Political Forum in New York or Regional Forum for Sustainable Development in Geneve; leading two international projects focused on the UN 2030 Agenda and becoming part of the IFLA Library Map of the World with Stories; producing several international documents which support the capacity building for librarians towards 2030; organizing local events for raising awareness about the SDGs among general population; getting recognized by the UN office in Serbia for all of the efforts being made to achieve the global goals.

As described, this paper presents what was achieved between December 2016 and October 2018, and opens further questions and opportunities for libraries in Serbia.

Keywords: sustainable development goals, Agenda 2030, United Nations, access to information, advocacy, IFLA Serbian Library Association, libraries 


\section{(৫)৫}

Променада 2030 bу Весна Вуксан is licensed under a Creative Commons Attribution-NonCommercialNoDerivatives 4.0 International License. 